LiWei,

Postgraduate student, Sumy National Agrarian University

ORCID iD: 0000-0001-9855-229X

DOI: $10.32702 / 2306-6806.2019 .6 .59$

\title{
FEATURES OF MANAGEMENT OF LABOR POTENTIAL IN EDUCATIONAL SPHERE
}

\author{
Мi Вей, \\ аспірант, Сумський національний аграрний університет
}

\section{ОСОБАИВОСТІ УПРАВАІННЯ ТРУАОВИМ ПОТЕНЦІАЛОМ В ОСВІТНІЙ СФЕРІ}

In today's dynamic conditions, education is one of the most important social institutions of any country. It is indisputable that the labor potential becomes the main condition of social economy, scientific-technical, intellectual and spiritual development of one country.

The modern direction of education development requires radical changes, improvement of mechanisms of strategic management of labor potential, since labor potential needs constant development by improving its qualitative characteristics, first of all, through education and professional training.

The purpose of writing this scientific article is to summarize scientific approaches to the management of labor resources in the educational sphere and to identify the prionity directions of improvement of the management system.

The author analyzes the approaches of scientists to the interpretation of the concept of "labor resources", "labor potential".

In this scientific article, the stages of development of scientific approaches to the management of labor resources are distinguished from the theoretical position. The principles of the management of labor resources in the educational sphere are generalized.

It is believed that the human resources management system of colleges and universities should be continuously improved to adapt to the dynamic conditions of social development. It is very important to reform the management system, introduce a competitive mechanism, and improve employee efficiency. The labor resource management process in education should be based on the application of a progressive administrative approach.

Accordingly, new strategic approaches to the management of labor potential in the educational sphere should to determine the optimal quantitative and qualitative characteristics of workers and ensure that the number of employees corresponds to the economic needs, which, in turn, will form the basis for increasing the level of labor productivity and provide innovative development of labor potential.

In scientific works, the specific characteristics of labor resources in the educational sphere are identified, which should be taken into account when designing a management strategy.

У сучасних динамічних умовах срера освіти є одним з найважливіших суспільних інститутів будьякої країни. Беззаперечним є факт, що трудовий потенціал стає основною умовою соціально-економічного, науково-технічного, інтелектуального та духовного розвитку країни.

Сучасний напрям розвитку освіти вимагає докорінних змін, вдосконалення механізмів Стратегічного Управління трУАовим потенціалом, оскільки трудовий потенціал потребує постійного розвитку шАяхом покращення його якісних характеристик, насамперед, за рахунок освіти та професійної підготовки.

Метою написання наукової статті $є$ Узагальнення наукових підходів управління трудовими ресурсами в освітній сфері та виокремлення пріоритетних напрямів вдосконалення системи менеджменту.

Автором проаналізовано підходи науковців до інтерпретації поняття "трудові ресурси", "трудовий потенціал".

Унауковій Статті виокремлено з теоретичної позиції етапи розвитку наукових підходів до управАіння трудовими ресурсами. Узагальнено принципи управління трудовими ресурсами в освітній сфері.

Аргументовано, що система Управління Аюдськими ресурсами коледжів і університетів повинна постійно вдосконалюватися, адаптуватися до динамічних Умов розвиткУ суспільства. Особливої актуальності набуває питання реформування системи управління, впровадження конкурентних механізм, підвищення ефективності роботи працівників. Встановлено, що процес управління трудовими ресурсами в освітній сфері повинен в обов'язковому порядку базуватися на застосуванні прогресивних управлінських методів. 
Відповідно, нові стратегічні підходи до управління трудовим потенціалом в освітній сфері мають визначати оптимальні кількісно-якісні характеристики працівників та забезпечувати відповідність кількості працівників економічним потребам, які, в Свою чергу, сформують базис підвищення рівня ефективності праці та забезпечать інноваційний розвиток трудового потенціалу.

В науковій праці виокремлено особливі характеристики трудових ресурсів в освітній сфері, які повинні бути враховані при моделюванні управлінської стратегї.

Keywords: teachers in colleges and universities, buman resource, potential development, teacherpotential development, efficiency.

Ключові слова: вчителі в коледжах і університетах, управління персоналом, потенчіал розвитку, розвиток потенчіалу викладача, ефективність.

\section{INTRODUCTION}

At present, research on human resource management (HRM) is mainly concentrated in the enterprise field, and there are less researches on education. Researches on HRM in colleges and universities is on rising. Most researches focus on macro HRM. The key to HRM is to explore scientific methods and techniques, fully explore the potential of organizational members, and provide technical support for members development and organizational performance improvement, and enterprises have more research in this area.

How to apply the theory, methods and techniques in enterprise HRM and potential development to the HRM and potential development in colleges and universities is a problem that worthy of discussion. Therefore, this study will focus on exploring the convergence between the two.

Literature Review. The scientists and scholars who currently engaged in human resource management and potential development research mainly include: Zhao Yuming, Peter Drucker, Gary Desler, Hu Shuhong, Liu Guanhua, Ye Yingchun, Wang Maotian, Yang Shouzhong, Zhang Wenxian, Tao Yunwu, Song Ge, Cui Jinfu, Israel Scheffler, Yang Jingdong, Wang Tongxun, Shako Gawain and others.

The purpose of the article is a summary of the scientific methods of human resource management in the field of education, as well as the determination of the priority direction of the improvement of the management system.

The main results of the research. It is imperative to introduce the theory and method of HRM to colleges and universities, and it is necessary to pay attention to the efficiency improvement and potential development of individual teacher. The higher education can, like enterprises, form a theoretical system by constructing theoretical models, and form measurement tools for teacher potential development through technology development, and promote the theoretical and practical development of education HRM and potential development.

It can be seen from the development process of HRM that researchers pay more and more attention to the role of HRM in promoting organizational performance, which makes the HRM focus on HR development and human potential development.

HRM refers to according to the requirement of the enterprise development strategy, in a planned way to rational allocation of HR, through the enterprise staff recruitment, training, use, evaluation, motivation, adjustment and so on, arouse the enthusiasm of employees, develop their potential, create value for the enterprise, bring benefit to the enterprise [1].

We believe that HRM should be refers to a certain organization, using scientific management methods, making use of organizational resources, by making the HR planning, recruitment and configuration, performance management, compensation and benefits management, training and HR development, labor relations management, and other activities, fully develop the potential of members, maximize organizational efficiency, finally realizes the organization development targets.

HRM is to improve the value of workers in both economics and psychology. The important part is the development of HR. The core of it is to develop human potential. The goal is to improve individual performance. Realize the common development of individuals and organizations.

The HR of colleges and universities should refer to the total labor capacity of laborers engaged in teaching, scientific research, management, and service in higher education institutions.

According to the nature of work, the HR of colleges and universities can be divided into management personnel,

Table 1. Stage characteristics of HRM [5]

\begin{tabular}{|l|l|l|l|}
\hline \multicolumn{1}{|c|}{ Stages } & \multicolumn{1}{|c|}{ Period } & \multicolumn{1}{c|}{ State of play } & \multicolumn{1}{c|}{$\begin{array}{c}\text { Management system } \\
\text { functions }\end{array}$} \\
\hline $\begin{array}{l}\text { Personnel } \\
\text { managemen } \\
\text { t stage }\end{array}$ & $\begin{array}{l}\text { From the 1950s } \\
\text { to the 1970s }\end{array}$ & $\begin{array}{l}\text { 1. Lack of professional management system and } \\
\text { management experience. } \\
\text { 2. The main work is to record personnel files. } \\
\text { 3.Not treating members as HR. }\end{array}$ & Staff emoluments \\
\hline Transitory & $\begin{array}{l}\text { From the 1970s } \\
\text { to the 1990s }\end{array}$ & $\begin{array}{l}\text { 1. Expanded the work to formulate and issue } \\
\text { personnel policies, recruit and manage employees, } \\
\text { implement HR development plans. } \\
\text { 2. The embryonic form of HRM appeared, but the } \\
\text { deep-seated problems of HR were still not considered }\end{array}$ & $\begin{array}{l}\text { Hesign, generate and } \\
\text { analyze preliminary } \\
\text { reports for non-financial } \\
\text { salary information }\end{array}$ \\
\hline $\begin{array}{l}\text { System } \\
\text { HRM stage }\end{array}$ & to present & $\begin{array}{l}\text { 1. HRM becomes the maker and executor of } \\
\text { enterprise HR development strategy. } \\
\text { 2. Start to consider HRM strategy and implement } \\
\text { strict management. } \\
\text { 3. In order to improve the members and performance } \\
\text { of the organization, HRM planning consistent with } \\
\text { the strategic objectives of the organization was } \\
\text { started }\end{array}$ & $\begin{array}{l}\text { Almost all data related to } \\
\text { HR are collected and } \\
\text { managed. Powerful } \\
\text { report generation tools, } \\
\text { data analysis tools and } \\
\text { information sharing } \\
\text { functions }\end{array}$ \\
\hline
\end{tabular}


Table 2. Basic principles of HRM [3]

\begin{tabular}{|c|c|}
\hline Fundamental Principles & Principle explanation \\
\hline The isomeric principle & $\begin{array}{l}\text { The same number and quality of people, different } \\
\text { organizational networks and functions will form } \\
\text { different power and responsibility structures and } \\
\text { collaborative relationships, resulting in different } \\
\text { synergies }\end{array}$ \\
\hline $\begin{array}{l}\text { Energy Level Matching and } \\
\text { the Principle of Suitability }\end{array}$ & To make the best use of one's talents and materials \\
\hline $\begin{array}{l}\text { Strengthening Rewards and } \\
\text { Punishments and the } \\
\text { Principle of Fair } \\
\text { Competition }\end{array}$ & $\begin{array}{l}\text { Through rewards and punishments fair competition } \\
\text { mechanism is introduced to improve the work efficiency } \\
\text { of employees }\end{array}$ \\
\hline $\begin{array}{l}\text { Principle of Dynamic } \\
\text { Excitation }\end{array}$ & $\begin{array}{l}\text { Use personnel adjustment, guide personnel reasonable } \\
\text { flow to stimulate organizational vitality and improve } \\
\text { organizational efficiency }\end{array}$ \\
\hline $\begin{array}{l}\text { Complementary Value- } \\
\text { added Principle }\end{array}$ & $\begin{array}{l}\text { Use individual difference of employee to develop strong } \\
\text { points and avoid weak points, realize HR system } \\
\text { optimization }\end{array}$ \\
\hline $\begin{array}{l}\text { The Unification Principle of } \\
\text { Virtue and Talent }\end{array}$ & $\begin{array}{l}\text { Take employee ethics and talent as the connotation and } \\
\text { standard of talent selection, use, cultivation and retention }\end{array}$ \\
\hline $\begin{array}{l}\text { Principle of Human Capital } \\
\text { and Income }\end{array}$ & $\begin{array}{l}\text { HR development needs input cost and benefits at the } \\
\text { same time. HR development in different fields has its } \\
\text { own characteristics }\end{array}$ \\
\hline
\end{tabular}

professional and technical personnel, workers and other employees, among which professional and technical personnel refer to full-time teachers and auxiliary teaching personnel with professional and technical titles and engaged in teaching and scientific research or other corresponding work.HR in colleges and universities have the following characteristics: with high degree and professional knowledge background, strong autonomy in working hours, strong mobility and preference.

Colleges and universities as typical social public services, its own characteristics different from general enterprise organizations. The HRM also has particularity, the introduction of HRM theory and method is also later. At present, some colleges and universities is still in the stage of personnel management, most colleges and universities are actively explore the scientific HRM methods and techniques to develop teachers' potential, improve the efficiency of organization.

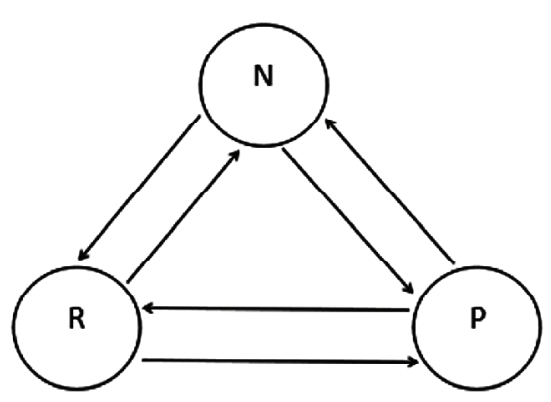

N:Need; R:Reality; P:Potential.

Figure 1. Relationship between human needs, potential and reality [9]

Table 3. The distinction of relevant concept category [5]

\begin{tabular}{|c|c|c|c|}
\hline Concepts & Definitions & Characteristics & Components \\
\hline Ability & $\begin{array}{l}\text { Ability is the psychological characteristic } \\
\text { necessary to complete the activity, which } \\
\text { directly affects the activity efficiency and } \\
\text { can make the activity go on smoothly }\end{array}$ & $\begin{array}{l}\text { 1.Always connect with activities. } \\
\text { 2. Directly affect the efficiency of } \\
\text { activities } \\
\text { 3. The psychological. } \\
\text { 4. Strong generality, covering a wide } \\
\text { range }\end{array}$ & $\begin{array}{l}\text { 1. Thinking ability. } \\
\text { 2. Behavior ability. } \\
\text { 3. Language }\end{array}$ \\
\hline Personality & $\begin{array}{l}\text { In the process of socialization, individuals } \\
\text { form and develop a unique pattern of } \\
\text { thought, emotion and behavior }\end{array}$ & $\begin{array}{l}\text { 1. Unique individual } \\
\text { 2. Stable and unified } \\
\text { 3. Comprehensiveness } \\
\text { 4. Harmony and unity } \\
\text { 5. Functionality }\end{array}$ & $\begin{array}{l}\text { 1. Id. } \\
\text { 2. Ego } \\
\text { 3. Superego }\end{array}$ \\
\hline Skill & Mastery and application of technical skills & $\begin{array}{l}\text { 1. Only by learning in person can we } \\
\text { acquire it. } \\
\text { 2. Practice makes perfect physical } \\
\text { activity. } \\
\text { 3. Eye-hand coordination ability }\end{array}$ & $\begin{array}{l}\text { 1. Professional Skills } \\
\text { 2. Sports Skills }\end{array}$ \\
\hline Competency & $\begin{array}{l}\text { The objective measurable individual } \\
\text { characteristics and the predictable } \\
\text { behavioral characteristics that point to } \\
\text { performance of high performers in specific } \\
\text { jobs, organizational environment and } \\
\text { cultural atmosphere }\end{array}$ & $\begin{array}{l}\text { 1. Connecting with Situations. } \\
\text { 2. Predictability. } \\
\text { 3.Linking to performance. } \\
\text { 4. Integration: dominance and recessive }\end{array}$ & $\begin{array}{l}\text { 1. Knowledge. } \\
\text { 2.Skills. } \\
\text { 3. Self-image. } \\
\text { 4. Social motivation. } \\
\text { 5.Quality }\end{array}$ \\
\hline Potential & $\begin{array}{l}\text { The latent ability of an individual to } \\
\text { contribute to the performance of an } \\
\text { organization or individual by exerting } \\
\text { influence }\end{array}$ & $\begin{array}{l}\text { 1. Deep-seated. } \\
\text { 2. Visible. } \\
\text { 3. Measurable. } \\
\text { 4. Learning Enhanced. } \\
\text { 5.Indirect display }\end{array}$ & $\begin{array}{l}\text { 1. Internal drive. } \\
\text { 2. Self-concept. } \\
\text { 3.Individual character. } \\
\text { 4. Attitude }\end{array}$ \\
\hline
\end{tabular}




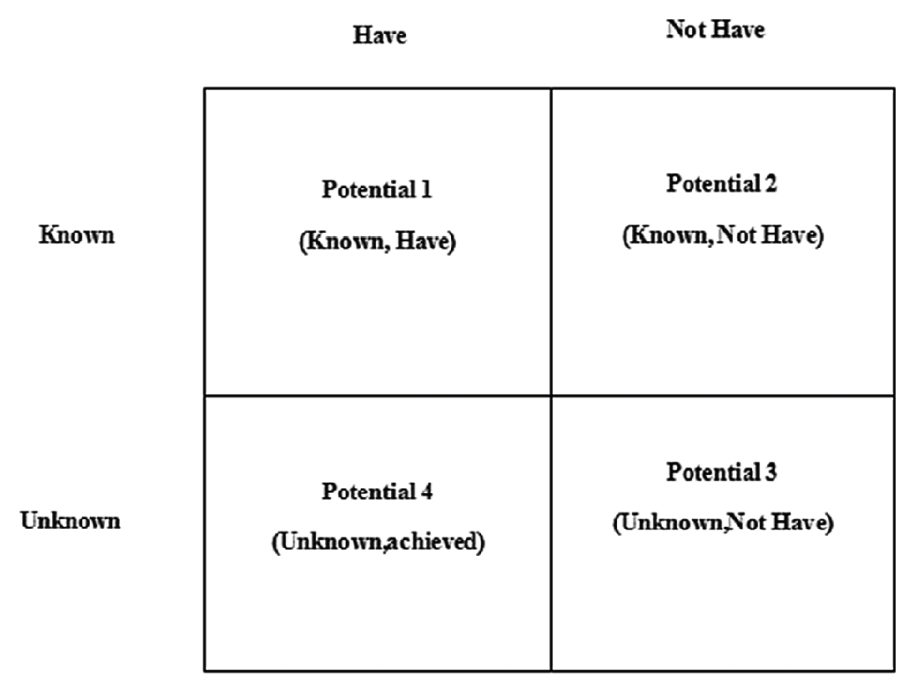

Figure 2. Classification of potential [7]

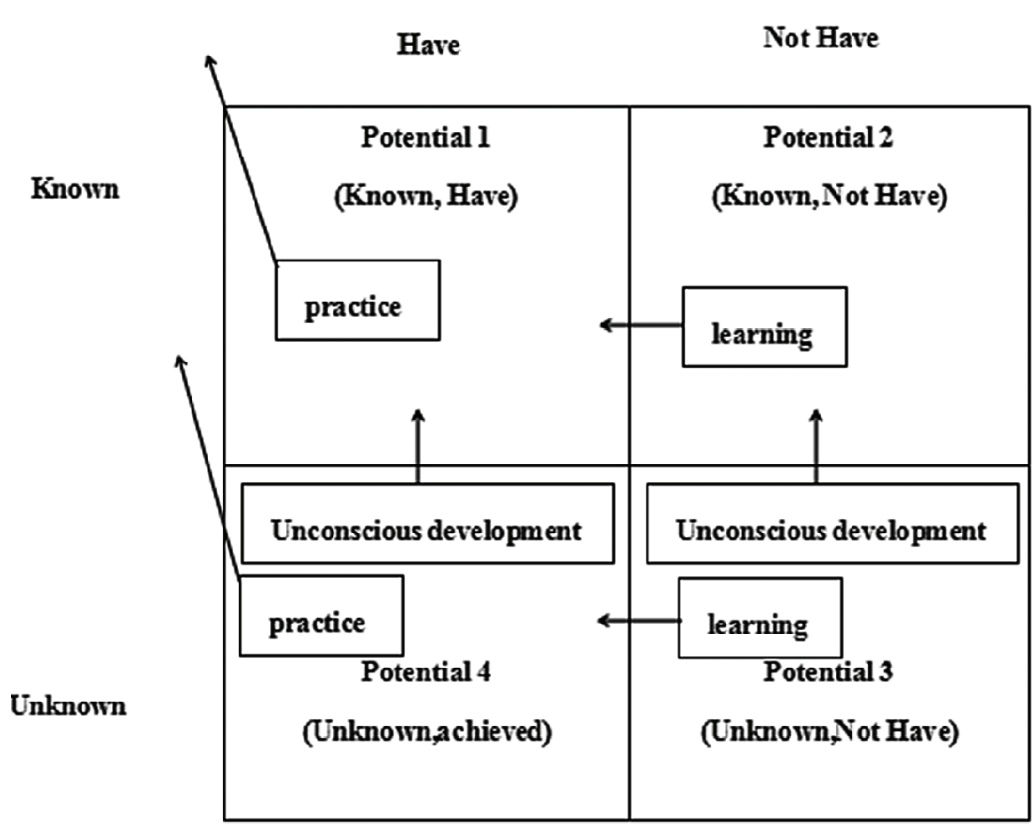

Figure 3. Potential window [7]
In 2013, researcher Guo Zhiping combed the basic principles of education HRM (Table 2 ), as a guiding principle for educational HRM activities, and guided HRM of education

In this research we define HRM of colleges and universities as: the integrated use of scientific management methods, through the formulation reasonable HR planning, recruitment and configuration faculty, staff performance management, compensation and benefits management, training, labor relations management and other activities, fully develop the potential of each staff, improve the efficiency, finally achieve the aims of the school.

The traditional concept of potential is mainly represented by Aristotle and Hegel, who described the concept of potential from the perspective of their respective philosophical theories. Aristotle thought, "Potential" (Ddunamis in Greek) and "Reality" (Energeia in Greek) were two basic pairs of categorization inseparable from "material" and "form"[8].

According to Cui Jinfu, the definition of potential is the strong, inevitable tendency to define potential as marked or foreshadowed

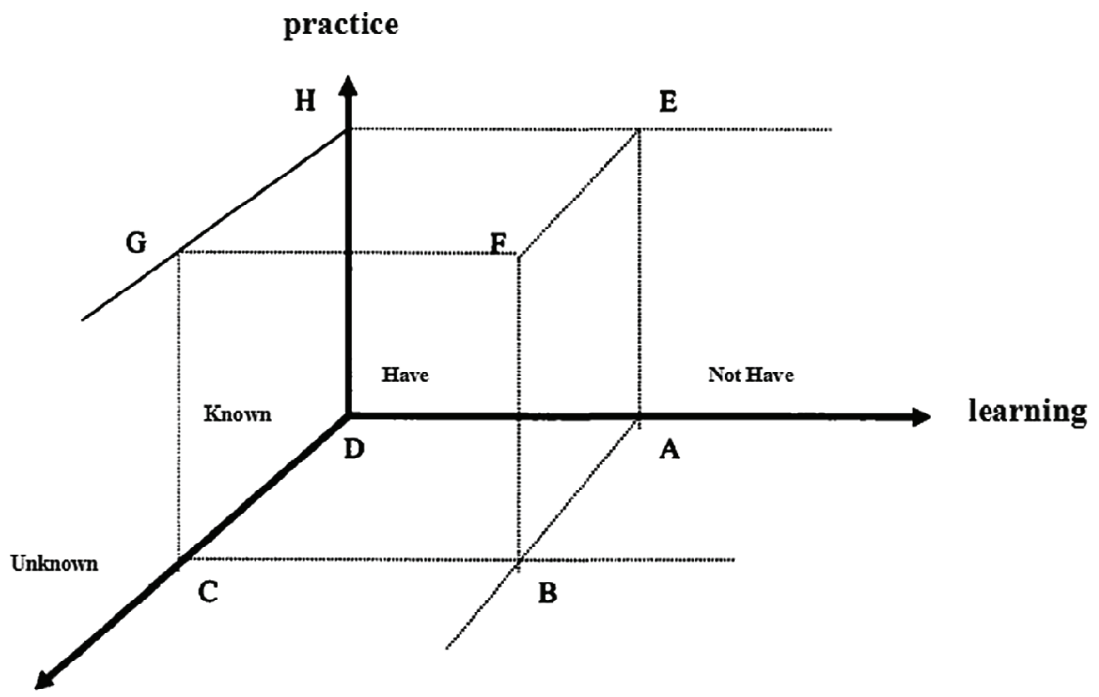

Unconscious development

Figure 4. Three dimensions of employee potential development [7] 
by human reality. He believed that the need of a certain stage is the original power of human development. Potential is the necessary tendency to satisfy need. Reality is the realization of potential, the real satisfaction of the need, and then a new need comes out, starting a new movement from need to potential and reality(Figure 1). But we think his concepts of potential and motivation intersect and even confuse.

According to T.Schultz (1961) human potential is the knowledge, skills and disposition, or "ability" in common sense of individuals or groups. He equated "potential" with "talent". Yang Jingdong (2003) thought that the potential is people's underlying ability. Wang Tongxun (2001), Shako Gawain (1998) and others believed that human potential is a kind of energy. Tao Yunwu defined potential as an unexposed ability. In psychology, potential is interpreted as the ability that an individual may show on behavior when he has the opportunity to learn in the future, which is a potential and future-oriented ability tendency with great plasticity [7].

Based on the above studies, we believe that potential should be defined as the sum of the abilities that have not been discovered or have not been shown but it has a positive effect on individual development.

Potential, as a kind of human personality, has certain differences and connections with other traits. In order to clarify the relationship between various traits, it is necessary to distinguish potential from other traits (Table 3 ).

According to Table 3 we can see that personality refers to the sum of a certain and more stable psychological characteristics. Competency refers to the specific characteristics of individuals who can distinguish between those who have outstanding achievements in a job and ordinary people according to the analysis, personality includes all of the above qualities. Ability includes skill competency and partial potential. Competency includes some skills and potentials.

In 2006, Tao Yunwu combined the famous Johari window theory in psychology to classify potentials (Figure 2 ) and construct a potential window theory(Figure 3 ). He also built a 3D model of employee potential development (Figure 4). He believed that the approaches of employee potential development include learning, practice and unconscious development. Different types of potential need to be developed in different ways.

Tao Yunwu divided potential into four types according to whether or not human knows and whether or not human have. Potential 1: Human has and also knows that he has this ability; Potential 2: Human clearly knows what is lacking; Potential 3: Already have, but I have not realized it. Potential 4: I don't know what I lack.

If we want to develop the potential that we don't know, first of all, it must enter the consciousness, so unconscious development is the best way. We realize that the potential that we have not yet had can be got through learning. The best way to translate potential into specific abilities is practicing. Therefore practice, learning and unconscious development is the three dimensions of potential development. It can be seen from the Figure 4 that through learning and unconscious development, potential 1 is getting larger and larger, while the range of potential 2, potential 3 and potential 4 is getting smaller and smaller. But potential 1 is still potential, we need practice to turn potential into reality.

As can be seen from Figure 4, Through practical learning and unconscious development, the space between $\mathrm{A}-\mathrm{B}-\mathrm{C}-\mathrm{D}-\mathrm{E}-\mathrm{F}-\mathrm{G}-\mathrm{H}$ is growing, and the ability of people is growing.

Through theoretical research, Tao Yunwu constructed a theoretical model of employee potential, compiled a questionnaire for measuring employee potential development, tested the reliability and validity of the questionnaire, tested and analyzed employee potential through empirical research, and proposed effective strategies for employee potential development in enterprises. Tao Yunwu's research for the first time put forward the use of psychological model for employee potential research, which has certain inspiration and guidance for us to study the model of potential development.

This study believes that university human resource management systems need to introduce the technology of scientific human resource management, and gradually pay attention to efficiency improvement while adhering to fairness. The management system should be promoted to develop a scientific human resource management system that is conducive to the development of teachers' potential and efficiency.

At the micro level, the purpose of this study is to investigate the basic situation of the potential development of college and university teachers. Using a certain psychological theory model to study the basic structure and basic dimensions of college and university teachers' potential, through the use of certain techniques to compile the tools to measure the potential of college and university teachers, to explore the main problems in the development of college and university teachers' potential, and to propose methods and techniques to promote their potential development.

\section{CONCLUSIONS}

First, it is necessary to pay attention to the research of HRM in colleges and universities, and use the theories, methods and techniques of scientific HRM to promote the development of HRM in colleges and universities.

Secondly, the researches on the potential development of college and university teachers lacks systematic, theoretical construction and necessary theoretical system. The theoretical system can be formed by constructing a theoretical model.

Third, there are few applied researches on the potential development of college and university teachers, and there is no measurement tool and application technology for guiding the development of teachers' potential.

These are the problems that this research is committed to solving and will become the innovation and value of this research.

\section{References:}

1. Zhao Yuming, (2001), Human Resource Management Research, Chinese People's Publishing House, Beijing, China.

2. Peter Drucker, (2009), Management Practice, Mechanical Industry Press, Beijing, China.

3. Guo Zhiping, (2013),"HRM and development of basic education in lusong district",M.B.A. Thesis, Business management, Hunan University of Technology,Zhuzhou, China.

4. Hu Shuhong and Liu Guanhua, (2011), "Exploratory Research on High Performance Work System of college and university teachers in Inner Mongolia", Journal of Inner Mongolia Normal University, vol.26, p.34-38.

5. Ye Yingchun and Wang Maotian(2009), "Research on the development of professional competence of enterprise managers", Business strategy, vol. 10, p. 70-71.

6. Gary Desler, (2001), Human Resource Management (eighth edition), Tsinghua University Press, Beijing, China.

7. Zhang Wenxian and Tao Yunwu, (2006), "3D model of employee potential development", Human Resources, vol. 17, p. $61-65$.

8. Israel Scheffler, (2006), Human potential, East China normal university press, Shanghai, China.

9. Cui Jinfu, (1995), "Philosophical implications of human potential?Human potential and its needs, possibilities and realities", Journal of Yunnan Normal University, vol. 4, p. $43-50$.

Стаття надійшла до редакиї 22.05.2019 p. 